\title{
Stabiliteit en verandering in intergenerati- onele familierelaties \\ Verschuivingen in relatietypen over een periode van drie jaar
}

\author{
Pearl A. Dykstra \& Niels Schenk ${ }^{1}$
}

\section{Summary}

Continuity and change in intergenerational family relationships:An examination of shifts in relationship type over a three-year period

This paper focuses on shifts in adult child-parent relationship type using the first two waves of the Netherlands Kinship Panel Study (NKPS). The analyses are informed by both a life transitions perspective, and the negotiation of relationships perspective. The intergenerational relationships typology represents different combinations of solidaristic acts and conflict. We employed Latent Transition Analysis to determine the prevalence and predictors of shifts. Less than $5 \%$ of the dyads shifted to a different type. Insofar shifts took place, they were most likely from the ambivalent type, and particularly so for relationships with mothers and daughters. Offspring (re)partnering, offspring divorce, parental widowhood, parental health decline, offspring unemployment, birth of a grandchild, and moving nearer, did not predict typology shifts, whereas the number of parental divorces was too small for analyses of change. Parental repartnering prompted a shift towards the discordant type with its low probabilities of contact and support exchange, and the relatively high likelihood of conflict over personal issues. Moving away prompted a shift from the ambivalent type with its high probabilities of supportive exchanges and conflict over material and personal issues. Over a period of three years, there is considerably more continuity in adult child-parent relationships than change.

\section{Inleiding}

Veranderingen in intergenerationele familierelaties gedurende de levensloop zijn op verschillende manieren onderzocht. Een van de bena- 
deringen richt zich op levenstransities en de relaties met oudere en jongere generaties. De verwevenheid tussen de levens van familieleden (linked lives) wordt vaak aangehaald om te illustreren hoe individuele beslissingen niet alleen gevolgen hebben voor het eigen leven, maar ook voor de interactie met familieleden (Elder, 1994; Hagestad, 2003). Binnen dit onderzoeksgebied is het meeste onderzoek gedaan naar de gevolgen van ouderlijke echtscheiding. Het algemene beeld dat hieruit naar voren komt, is dat echtscheiding in de oudere generatie een vermindering van uitwisselingen met de jongere generatie tot gevolg heeft. Dit geldt in sterkere mate voor vaders dan voor moeders (Kalmijn, 2007).

Veranderingen in familierelaties zijn ook onderzocht met betrekking tot verschillende stadia in de levensloop. Zo wordt er bijvoorbeeld in individuation theory verondersteld dat de relatie met ouders moet worden heronderhandeld tijdens de adolescentie door de groeiende gelijkwaardigheid tussen ouders en kinderen die de overgang naar volwassenheid met zich meebrengt (Grotevant \& Cooper, 1986). Deze toegenomen gelijkwaardigheid in de relatie met de ouders zou de condities scheppen voor de verdere psychosociale ontwikkeling van kinderen. Onderzoek in Nederland laat zien dat er tijdens de adolescentie sprake is van zowel toegenomen zelfstandigheid als een voorzetting van de verwantschap met de ouders die al bestond (Bucx, 2009). Naast de processen die zich afspelen tijdens de overgang naar adolescentie, vinden er, later in het leven, veranderingen plaats wanneer volwassen kinderen worden geconfronteerd met de mogelijk groeiende kwetsbaarheid van hun ouders. Dit proces wordt in de Engelstalige literatuur aangeduid als filial maturity (Cicirelli, 1988; Marcoen, 1995), waarmee wordt geduid op de empathische vermogens van kinderen om hun steeds kwetsbaardere ouders met respect tegemoet te treden zonder dat daarbij hun eigen en hun ouders' autonomie verloren gaat.

Deze tweestrijd tussen enerzijds autonomie en anderzijds afhankelijkheid bij het doorlopen van verschillende levensstadia staat ook centraal in de literatuur naar ambivalentie binnen familierelaties (Katz, Lowenstein, Phillips, \& Daatland, 2005; Kiecolt, Blieszner, \& Savla, 2011; Pillemer \& Suitor, 2002; Willson, Shuey, Elder, \& Wickrama, 2006). Vanuit psychologisch oogpunt houdt ambivalentie in dat men tegelijkertijd zowel warme als vijandige gevoelens ten opzichte van een familielid kan hebben (Lüscher \& Pillemer, 1998). In de sociologie wordt onder ambivalentie verstaan dat institutionele krachten concurrerende en tegenstrijdige invloeden uitoefenen op de hulpbronnen van familieleden (Connidis \& McMullin, 2002). Pogingen van familieleden om met ambivalentie om te gaan brengen veranderingen in de relatie met zich mee (Bengtson, Giarrusso, Mabry, \& Silverstein, 2002; Connidis \& McMullin, 2002; Lüscher, 2002): verwijdering, toenadering, intensivering, enzovoorts. Het 
ambivalentieperspectief benadrukt de dynamiek in familierelaties die gepaard gaat met heronderhandeling (Connidis, 2010). Overigens moet worden opgemerkt dat niet alle auteurs van mening zijn dat ambivalentie in ouder-kindrelaties oplosbaar is (zie bijvoorbeeld Lüscher, 2002). Daarnaast moet worden opgemerkt dat dynamiek in familierelaties uiteraard niet alleen aan ambivalentie is toe te schrijven; belangrijke levenstransities zorgen ook vaak voor een heroverweging van de relatie met familieleden.

Waar de voorgaande theoretische perspectieven veranderingen in familierelaties centraal stellen, wordt in andere juist de stabiliteit van relaties benadrukt (Rossi \& Rossi, 1990). Stabiliteit in familierelaties is consistent met voorspellingen van de gehechtheidstheorie (Ainsworth, 1989). Volgens deze theorie worden vroege ervaringen van gevoelens van veiligheid, angst en zorg in de ouder-kindrelatie geïnternaliseerd en dienen deze als model voor de omgang met anderen gedurende de rest van het leven. Deze ervaringen in de vroege kindertijd geven niet alleen vorm aan toekomstige relaties, maar worden ook aangeroepen bij ingrijpende gebeurtenissen (Merz, 2010).

In dit artikel richten wij ons op stabiliteit en veranderingen in de relaties van volwassen kinderen met hun ouders gedurende een periode van drie jaar. We doen dit door verschuivingen in zogenaamde relatietypen te onderzoeken. In hoeverre veranderen ouder-kindrelaties van type en in hoeverre blijft hun type ongewijzigd? In navolging van Van Gaalen en Dykstra (2006) verstaan we onder een type een combinatie van verschillende dimensies van solidariteit (zoals de frequentie van persoonlijk contact) en conflict (zoals ruzie over politieke opvattingen).

In ons theoretisch kader gebruiken wij inzichten over de gevolgen van belangrijke levenstransities voor familierelaties en die over heronderhandeling bij ambivalentie in familierelaties. Wij dragen op drie manieren bij aan de literatuur. Ten eerste houden we rekening met de complexiteit van ouder-kindrelaties door via een typologie verschillende dimensies van solidariteit en conflict tegelijkertijd in ogenschouw te nemen. Ten tweede richten wij ons op gebeurtenissen in de levens van zowel volwassen kinderen als hun ouders. Ten derde onderzoeken wij of sommige typen ouder-kindrelaties een grotere kans hebben om te veranderen dan andere. Met deze benadering streven wij ernaar om een genuanceerder beeld van stabiliteit en verandering in familierelaties te verkrijgen. Wij gebruikten de eerste twee rondes van de Netherlands Kinship Panel Study (NKPS) (Dykstra, Kalmijn, Komter, Knijn, Liefbroer, \& Mulder, 2005; 2007), de Nederlandse deelnemer in het Generations and Gender Programme (United Nations Economic Commission for Europe, 2007). 


\section{Verschillende relatiedimensies}

Het overgrote deel van het longitudinale onderzoek naar veranderingen in intergenerationele familierelaties beperkt zich tot een enkele dimensie: hetzelfde huishouden delen (bijvoorbeeld Smits, Van Gaalen, \& Mulder, 2010), financiële uitwisselingen (bijvoorbeeld Shapiro \& Remle, 2010; Sheng \& Killian, 2009), emotionele steun (bijvoorbeeld Ha, 2008) of gepercipieerde relatiekwaliteit (bijvoorbeeld Kaufman \& Uhlenberg, 1998). Zelfs wanneer prospectieve studies meerdere dimensies meenemen, worden deze dimensies nog steeds afzonderlijk van elkaar bekeken (Aquilino, 1997; Ha, Carr, Utz, \& Nesse, 2006; Roan \& Raley, 1996; Shapiro, 2003). Onderzoek waarbij de onderlinge afhankelijkheid van relatiedimensies wordt onderkend is zeldzaam (zie voor uitzonderingen: Couch, Daly, \& Wolf, 1999; Koh \& MacDonald, 2006; Silverstein, Gans, \& Yang, 2006).

In cross-sectionele studies is meer aandacht besteed aan de complexiteit van ouder-kindrelaties in termen van configuraties van verschillende soorten van steun (financieel, emotioneel, praktisch, enzovoorts) en tegenstrijdige emoties (Silverstein \& Giarrusso, 2010). Een typologie is een geschikt onderzoeksmiddel om de complexiteit van ouder-kindrelaties in kaart te brengen. Een typologische benadering maakt het beter mogelijk om genuanceerd inzicht te verkrijgen in samenhangen tussen verschillende dimensies dan de veel gebruikte lineaire technieken. Een van de eerste typologieën van ouder-kindrelaties was die van Silverstein en Litwak (1993). Zij onderscheidden twee componenten op basis van factoranalyse: een sociaal-emotionele en een praktisch-huishoudelijke component. Kwaliteit van de relatie gold als voorspeller voor de mate van sociaal-emotionele steun terwijl de mate van hulpbehoevendheid van de ouder en geografische afstand de mate van praktisch-huishoudelijke steun voorspelden. Latere typologieën werden op basis van latente klasseanalyse geconstrueerd. In de typologie van Hogan, Eggebeen en Clogg (1993) was het belangrijkste onderscheid of steun 'naar boven' of 'naar beneden' werd gegeven. Silverstein en Bengtson (1997) richtten zich op combinaties van verwantschap (emotionele nabijheid en gepercipieerde overeenstemming), gelegenheidsstructuur (mate van contact en geografische nabijheid) en functie (de richting van steun). Recenter werden zowel positieve als negatieve aspecten van intergenerationele relaties in samenhang beschouwd. Affectie en conflict staan centraal in de typologie van Giarusso en collega's (Giarrusso, Silverstein, Gans, \& Bengtson, 2005), en die van Silverstein en collega's (Silverstein, Gans, Lowenstein, Giarrusso, \& Bengtson, 2010). De typologie van Steinbach (2008) betreft ook zowel conflict als intimiteit, maar is gebaseerd op een cross-classificatie in plaats van latente klasseanalyse. Zoals eerder is vermeld, ontwik- 
kelden Van Gaalen en Dykstra (2006) een typologie op basis van verschillende dimensies van solidariteit en conflict.

De wens en noodzaak om longitudinale studies te verrichten naar verschuivingen in typen als gevolg van levenstransities in de levens van ouder en kind, of als gevolg van heronderhandeling van de intergenerationele relatie, is al eerder onderkend (Bengtson et al., 2002; Giarrusso et al., 2005). Voor zover wij weten zijn wij de eersten die hier ook daadwerkelijk onderzoek naar doen. Als uitgangspunt nemen wij de typologie van ouder-kindrelaties op basis van de eerste ronde van de NKPS (Van Gaalen \& Dykstra, 2006). Eerst beschrijven we de typologie en vervolgens stellen we hypothesen op over hoe levenstransities van ouder en kind, en de heronderhandeling van de ouder-kindrelatie leiden tot verschuivingen in relatietypen. Deze verschuivingen worden vastgesteld door typen ten tijde van de eerste wave van de NKPS te vergelijken met die in de tweede. De hypothesen hebben uitsluitend betrekking op verschuivingen naar een bepaald relatietype.

In de typologie van Van Gaalen en Dykstra (2006) bestonden de solidariteitsdimensies uit persoonlijk contact, andere vormen van contact dan persoonlijk (telefonisch, schriftelijk, e-mail), praktische steun verleend aan ouders, praktische steun verleend aan volwassen kinderen, financiële steun verleend aan volwassen kinderen en uitwisseling van emotionele steun. De conflictdimensies bestonden uit: onenigheid over materiële zaken en onenigheid over persoonlijke zaken. Op basis van latente klasseanalyse werden vijf relatietypen onderscheiden: harmonieus (hoge kans op uitwisseling van emotionele steun, matige kans op praktische steun naar boven en naar beneden en een lage kans op conflict), ambivalent (hoge kans op uitwisseling van emotionele steun en praktische steun naar boven, een relatief hoge kans op financiële steun en praktische steun naar beneden en een relatief hoge kans op conflict, verplicht (hoge kans op persoonlijk contact, matige kans op uitwisseling van emotionele steun en op praktische steun naar boven, lage kans op financiële steun en op praktische steun naar beneden en een lage kans op conflict), affectief (hoge kans op contact anders dan persoonlijk en op uitwisseling van emotionele steun), en tenslotte verwijderd (lage kans op welke vorm van uitwisseling van steun dan ook en een relatief hoge kans op conflict over persoonlijke zaken). De gevonden typologie was robuust voor verschillende groepen van ouder-kindcombinaties samengesteld op basis van geslacht en leeftijd. 


\section{Theoretisch kader}

\section{I Levenstransities}

Om hypothesen over levenstransities en veranderingen in relatietypen te formuleren maken we gebruik van de begrippen mogelijkheidsstructuur en behoeftestructuur uit Szydliks (2008) publicatie over intergenerationele solidariteit en conflict. Onder mogelijkheidsstructuur verstaat hij condities zoals tijd en energie die sociale interacties vergemakkelijken of bemoeilijken. Tot de behoeftestructuur behoren financiële, emotionele en aan gezondheid-gerelateerde noden die door middel van sociale interacties kunnen worden voldaan. Levenstransities gaan vergezeld van veranderingen in een breed spectrum aan mogelijkheden en behoeften, met inbegrip van die voor sociale relaties (Lachman, 2004). Wij veronderstellen dat veranderingen in mogelijkheden voor en behoeften aan intergenerationele interacties op hun beurt zorgen voor verschuivingen in relatietypen. De transities die wij beschouwen hebben betrekking op partnerschap, gezondheid, werk, ouderschap en geografische afstand. In het onderstaande bespreken wij hoe de verschillende transities mogelijkheden voor en behoeften aan intergenerationele interacties structureren. We formuleren hypothesen over daarmee samenhangende verschuivingen in relatietypen. De voorspelde verschuivingen worden samengevat in tabel 1 .

\section{I.I Partnerschap}

Er bestaan tegenstrijdige ideeën over hoe partnerschap en huwelijk van invloed zijn op sociale interacties. Enerzijds wordt gesteld dat de privatiserende rol van het huwelijk ervoor zorgt dat men zich terugtrekt uit

Tabel 1 Samenvatting van de voorspelde verschuivingen in typen relaties

\begin{tabular}{ll}
\hline Voorspeller & Verschuiving naar \\
\hline Levenstransitie & Verplicht \\
Herpartneren ouder & Verplicht \\
Herpartneren kind & Verwijderd \\
Scheiding ouder & Ambivalent, affectief \\
Scheiding kind & Harmonieus \\
Verweduwing ouder & Harmonieus, ambivalent \\
Verslechtering gezondheid ouder & Ambivalent \\
Werkloosheid kind & Harmonieus, ambivalent, verplicht, affectief \\
Geboorte kleinkind & Harmonieus, verplicht \\
Verhuizing dichterbij & Affectief \\
Verhuizing verder weg & \\
Relatieheronderhandeling & Harmonieus, verwijderd \\
Ambivalent &
\end{tabular}


sociale interacties, terwijl de beëindiging van een partnerrelatie ervoor zorgt dat men sociale interacties weer opzoekt (Coser \& Coser, 1974). Anderzijds wordt gesteld dat het huwelijk een sociaal-integrerende functie vervult, hetgeen tot precies de tegenovergestelde verwachtingen leidt (Durkheim, 1951). Empirisch onderzoek is in overeenstemming met de eerste visie. Het huwelijk leidt tot minder investeringen in relaties buiten die met de partner, deels door een afname van emotionele, praktische en financiële behoeften, deels door een gebrek aan tijd en energie. Kinderen met een partner hebben minder contact en minder steunuitwisselingen met hun ouder wordende ouders dan kinderen zonder partner of zij die gescheiden zijn (Bucx, Van Wel, Knijn, \& Hagendoorn, 2008; Sarkisian \& Gerstel, 2008). Weinig onderzoek is gedaan naar de gevolgen voor de relaties met volwassen kinderen van het opnieuw aangaan van een relatie of hertrouw door de ouders na een eerdere scheiding (Connidis, 2010). Vergeleken met ouders die geen relatiebeëindiging hebben meegemaakt, wordt er door hertrouwde ouders minder steun verleend aan (Amato, Rezac, \& Booth, 1995; White, 1992) en is er minder contact met (Bucx et al., 2008; De Jong Gierveld \& Peeters, 2003; De Graaf \& Fokkema, 2007; Lye, Klepinger, Hyle, \& Nelson, 1995) volwassen kinderen. Vermoedelijk is dit te wijten aan de voorkeur van de hertrouwden om te investeren in de nieuwe relatie, zodat er minder tijd en energie overblijven voor uitwisselingen met volwassen kinderen. Op basis van het voorgaande komen we tot de volgende hypothesen. (1) Het opnieuw aangaan van een relatie door ouders zorgt voor een verschuiving naar het verplichte type. (2) Het (opnieuw) aangaan van een relatie door volwassen kinderen zorgt voor een verschuiving naar het verplichte type. De hypothesen gaan uit van de privatiserende rol van partnerschap. Het verplichte type is gekenmerkt door een hoge kans op persoonlijk contact, maar lage kansen op uitwisselingen van steun en op conflict.

Veel studies hebben zich gericht op de vraag of ouderlijke scheiding tot een vermindering leidt van op latere leeftijd beschikbare steun van kinderen. Resultaten tonen in het algemeen aan dat ouderlijke scheiding nadelige effecten heeft voor intergenerationele steun en contact (in het bijzonder voor vaders), terwijl verweduwing juist een intensivering van steun aan de ouders teweegbrengt (zie Kalmijn, 2007, voor een overzicht). De afname van sociale interacties na een scheiding van ouders is vooral toe te schrijven aan een afname in mogelijkheden voor contact als gevolg van verhuizing en de aanwezigheid van een nieuwe partner. Er zijn echter in het algemeen ook minder emotionele behoeften aan contact omdat de relatie tussen ouder en kind is verstoord (Amato, 2010). Een toename van intergenerationele uitwisselingen na verweduwing hangt samen met de toegenomen behoefte aan emotionele en praktische steun door het verlies van een dierbare en levensgezel (Ha, 2008). Er 
is minder bekend over de effecten van scheiding van volwassen kinderen op intergenerationele uitwisselingen. Uit het meeste onderzoek blijkt dat gescheiden kinderen meer uitwisselingen met hun ouders hebben dan getrouwde kinderen (Dykstra, 1997, Sarkisian \& Gerstel, 2008; Spitze, Logan, Deane, \& Zerger, 1994). Een afname in uitwisselingen is echter ook gevonden (Umberson, 1992; White \& Peterson, 1995). Deze tegenstrijdige resultaten zouden te maken kunnen hebben met enerzijds de toegenomen behoeften aan emotionele, financiële en praktische steun van de kant van de gescheiden kinderen, en anderzijds een afname in beschikbare tijd en energie samenhangend met een uitbreiding van arbeidsuren, alleenstaand ouderschap en de psychologische verwerking van de scheiding. Volgens Connidis (2010) introduceert scheiding van volwassen kinderen ambivalentie in de ouder-kindrelatie. Ouders weten na een scheiding niet goed hoe om te gaan met hun kind en voormalige schoondochter of schoonzoon, en moeten een balans vinden tussen hun behoefte aan gehechtheid en de noodzaak om de autonomie van hun nageslacht te respecteren. Op basis van het voorafgaande komen wij tot de volgende hypothesen. (3) Ouderlijke scheiding zorgt voor een verschuiving naar het verwijderde type. Deze hypothese neemt de nadelige gevolgen van ouderlijke scheiding als uitgangspunt. (4) Scheiding van kinderen zorgt voor verschuivingen naar zowel het affectieve als het ambivalente type. Deze hypothese veronderstelt dat de gevolgen van scheiding in de jongere generatie verschillend kunnen zijn: voor sommigen een toenadering, voor anderen een toenemende onduidelijkheid in de relatie. (5) Ouderlijke verweduwing zorgt voor een verschuiving naar het harmonieuze type. Deze hypothese veronderstelt dat volwassen kinderen tegemoetkomen aan de gestegen behoeften van hun ouders door relatief veel emotionele en praktische steun te verlenen. Het harmonieuze type heeft een hoge kans op steun 'naar boven' en een lage kans op conflict.

\subsubsection{Gezondheid}

Intergenerationele steun stroomt primair van ouders naar kinderen. Ouders worden pas netto ontvangers van steun wanneer ze een leeftijd hebben bereikt waarop ze gezondheids- en mobiliteitsproblemen gaan ondervinden (Attias-Donfut, Ogg, \& Wolff, 2005; Fingerman, Pitzer, Chan, Birditt, Franks \& Zarit, 2011). Het ontvangen van hulp van kinderen kan zowel positieve gevoelens van nabijheid genereren maar ook - vooral wanneer de balans doorslaat naar afhankelijkheid - negatieve gevoelens van conflict en ontevredenheid (George, 1986). Op basis de voorgaande overwegingen komen we tot de volgende hypothese. (6) Een verslechtering van de gezondheid van de ouders zorgt voor verschui- 
vingen naar zowel het harmonische als het ambivalente type. Net als hypothese 4, gaat hypothese 6 ervan uit dat gevolgen van een levensgebeurtenis verschillend kunnen zijn. Hier betreft het verschil de kans op conflict; deze is groter bij het ambivalente type.

\subsubsection{Werk}

De literatuur geeft verschillende argumenten voor waarom de mate van steun die ouders geven in de vorm van tijd en geld zou kunnen verschillen, afhankelijk van de werksituatie van het volwassen kind (WadeBenzoni \& Tost, 2009). Volgens het altruïsmeperspectief zouden ouders geneigd zijn om het meest hulpbehoevende kind bij te staan. Volgens het ruilperspectief zouden ouders geneigd zijn om het kind bij te staan waar de kans het grootst is dat bewezen gunsten beantwoord zullen worden. Onderzoek naar schenkingen zijn in het algemeen in overeenstemming met het altruïsmeperspectief. Ouders geven meer financiële en praktische steun aan kinderen die studeren, werkloos zijn of er onevenredig slechter aan toe zijn dan de anderen (Fingerman, Miller, Birditt, \& Zarit, 2009; Kohli, 1999; McGarry \& Schoeni, 1997; Schenk, Dykstra \& Maas, 2010). Werk en steun verlenen aan ouders kunnen als concurrerende tijdsactiviteiten wordt beschouwd. Vandaar dat vaak wordt verondersteld dat een toename in de ene activiteit tot een afname van de andere leidt (zie bijvoorbeeld Couch, Daly, \& Wolf, 1999). Overigens laten studies zien dat de steunverlening aan ouders niet afhangt van de werksituatie van de jongere generatie (Moen, Robison, \& Fields, 1994; Ogg \& Renault, 2006; Pavalko \& Artis, 1997; Van Putten, Dykstra, Schippers, \& Vlasblom, 2010). Nog een ander perspectief stelt dat problemen in de levens van volwassen kinderen, zoals werkloosheid, gevoelens van ambivalentie bij ouders oproepen. Aan de ene kant bestaat er de behoefte om het nageslacht te helpen en te beschermen, terwijl er aan de andere kant teleurstelling is over het gebrek aan succes in de jongere generatie en twijfels over de opvoeding (Birditt, Fingerman, \& Zarit, 2010; Pillemer \& Suitor, 2002). Vanuit het altruïsmeperspectief, dat financiële hulp aan hulpbehoevende kinderen voorspelt, en het ambivalentieperspectief, dat conflicten voorspelt bij een voortdurende afhankelijkheid van volwassen kinderen, komen we tot de volgende hypothese. (7) Werkloosheid van een volwassen kind zal zorgen voor een verschuiving naar het ambivalente type. Het ambivalente type heeft van alle typen de hoogste kans op financiële steun aan kinderen en de hoogste kans op conflict. 


\section{I.4 Ouderschap}

Het ten minste af en toe zorgen voor kleinkinderen is vrij gebruikelijk (Hank \& Buber, 2009; Vandell, McCartney, Owen, Booth, \& Clarke-Stewart, 2003). Toch is er betrekkelijk weinig bekend over de invloed van het krijgen van kinderen op intergenerationele relaties. Sommige onderzoekers veronderstellen dat ouderschap ervoor zorgt dat jongvolwassenen minder energie en tijd hebben voor intergenerationele relaties (Rossi \& Rossi, 1990). Anderen zijn van mening dat de gelijkwaardigheid in status die ontstaat doordat volwassen kinderen zelf ook kinderen krijgen zorgt voor een grotere nabijheid in de relatie met oudere generaties (Glass, Bengtson, \& Dunham, 1986). Weer een ander standpunt is dat de komst van kinderen zorgt voor onenigheid over de opvoeding, verwachtingen over oppassen en contact met de kleinkinderen (Aquilino, 1997). Het moge duidelijk zijn dat de komst van kleinkinderen uiteenlopende gevolgen kan hebben voor de band tussen volwassen kinderen en hun ouders. Het gebruik van een typologie is uitermate geschikt om deze verschillen in hun samenhang te beschouwen. Bovendien zijn het krijgen van kinderen en steun verleend door ouders niet noodzakelijkerwijs onafhankelijk van elkaar. Onlangs bleek uit onderzoek dat de kans op de geboorte van nog een kind binnen acht tot tien jaar groter was als de grootouders op de kleinkinderen pasten (Kaptijn, Thomese, Van Tilburg, \& Liefbroer, 2010). Op basis van de voorafgaande overwegingen komen we tot de volgende hypothese. (8) De geboorte van een kleinkind zorgt voor verschuivingen naar het harmonieuze, ambivalente, verplichte of affectieve type. Ook hier gaan we ervan uit dat een levenstransitie verschillende gevolgen kan hebben voor intergenerationele relaties. Om uitspraken te doen over de condities waaronder de ene verschuiving waarschijnlijker is dan de andere, is informatie over de geschiedenis van de ouder-kindrelatie nodig en informatie over de broers en zusters van het volwassen kind (Van Gaalen, Dykstra, \& Komter, 2010). In dit artikel laten we die condities buiten beschouwing.

\section{I.5 Geografische nabijheid}

Onderzoek heeft herhaaldelijk aangetoond dat geografische nabijheid persoonlijk contact vergemakkelijkt, hetgeen weer de kans op uitwisselingen van praktische steun vergroot (Hank, 2007; Litwak \& Kulis, 1987). Regelmatig contact reduceert niet alleen de kosten van het geven, maar maakt ook dat familieleden beter op de hoogte zijn van elkaars behoeften. Verder weg wonen maakt het lastiger om familieleden praktisch bij te staan. Verschillende onderzoekers hebben naar voren gebracht dat geografische nabijheid geen exogene voorspeller van intergenerationele steun en contact is (Grundy \& Shelton, 2001; Tomassini, Wolf, \& Rosina, 
2003). Familieleden kunnen immers besluiten dichter bij elkaar te gaan wonen juist omdat er behoefte is aan steun. Op basis van registerdata lieten Smits, Van Gaalen en Mulder (2010) zien dat verweduwing, langdurige invaliditeit en slechte socio-economische omstandigheden ervoor zorgden dat volwassen kinderen bij hun ouders introkken en vice versa. Ook hadden ouderen met kleinkinderen een grotere kans om dichterbij te komen wonen dan ouderen die geen kleinkinderen hadden (Van Diepen \& Mulder, 2009). In voormalig West-Duitsland hadden vrouwen een grotere kans om een eerste kind te krijgen wanneer ouders in hetzelfde dorp woonden dan wanneer ouders verder weg woonden (Hank \& Kreyenfeld, 2003). Op basis van het voorafgaande komen we tot de volgende hypothesen. (9) Dichter bij elkaar komen wonen zorgt voor een verschuiving naar zowel het harmonieuze als het verplichte type. Deze hypothese veronderstelt een grotere kans op uitwisseling van praktische steun (harmonieus) en een grotere kans op persoonlijk contact zonder veel steunuitwisseling (verplicht) vanwege geografische nabijheid. (10) Verder weg van elkaar gaan wonen zorgt voor een verschuiving naar het affectieve type. Deze hypothese veronderstelt een grotere kans op contact op andere manieren dan persoonlijk vanwege geografische afstand.

\subsection{Heronderhandeling}

Een belangrijk thema binnen het onderzoek naar intergenerationele steunverlening is dat wederzijdse verantwoordelijkheden steeds aan onderhandeling onderhevig zijn (Connidis \& McMullin, 2002; Finch \& Mason, 1993). Een typologie geeft alleen een momentopname van de uitwisselingen die tussen ouders en kinderen plaatsvinden. Een dergelijk bevroren beeld versluiert de dynamiek van onderhandelingen. Eerder onderzoek heeft laten zien dat intergenerationele ambivalentie gepaard gaat met een lager psychisch welbevinden (Fingerman, Pitzer, Lefkowitz, Birditt, \& Mroczek, 2008; Katz, 2009; Kiecolt et al., 2011). Wij verwachten dat ouders en kinderen in met name ambivalente relaties gemotiveerd zullen zijn om aan hun relatie te werken omdat ze de onbehaaglijkheid en het ongemak waarin ze zich bevinden willen reduceren. Ambivalentie vraagt om ofwel een verschuiving naar een wederzijds ondersteunende band, of een verschuiving naar een meer afstandelijke relatie. Wij komen daarom tot de volgende hypothese. (11) Ambivalente relaties vertonen het grootste aandeel verschuivingen en wel in de richting van een harmonieus of verwijderd type. 


\section{Methode}

\section{I Respondenten}

Wij hebben gebruikgemaakt van gegevens van de eerste en tweede rondes van de Netherlands Kinship Panel Study (NKPS). Tijdens de eerste ronde $(2002-2004)$ werden 8161 thuiswonende mannen en vrouwen variërend in leeftijd van 18 tot 80 jaar ondervraagd (Dykstra et al., 2005). Aan de tweede ronde (2006 - 2007) deden 6091 respondenten mee (Dykstra et al., 2007). De respons in de eerste ronde was $45 \%$ en in de tweede ronde $74 \%$. De respons is lager dan in buitenlandse surveys, maar vergelijkbaar met die voor andere familiesurveys in Nederland. Gedetailleerde nonresponsanalyses toonden aan dat relatiekwaliteit geen voorspeller was van non-respons in de tweede ronde. Respondenten die een slechte relatie met hun familieleden rapporteerden, waren even geneigd om in de tweede ronde mee te doen als respondenten die een goede relatiekwaliteit rapporteerden.

Voor de analyses in dit artikel hebben wij ons beperkt tot respondenten die informatie verschaften over de relatie met hun ouders, voor zover zij in leven waren en voor zover de verblijfplaats bekend was. Dit resulteerde in $N=8065$ dyades voor ronde 1 en $N=5456$ dyades voor ronde 2. Tussen de twee rondes overleden 604 ouders en de betreffende dyades zijn niet meegenomen in de analyses op basis van de tweede ronde. De gegevens van ouders die in hetzelfde huishouden als de respondent woonden, werden niet meegenomen aangezien informatie ontbrak over patronen van interactie, de frequentie van contact, en uitwisselingen van steun. Het betreft 501 dyades in zowel de eerste als tweede ronde en 204 uit de tweede ronde. Theoretisch gezien zijn vooral relaties tussen ouders en kinderen die het huishouden delen vatbaar voor ambivalentie door de spanning tussen zelfstandigheid en afhankelijkheid (Kiecolt et al., 2011). Helaas zijn wij door databeperkingen niet in staat om op dit punt onderzoek te doen.

In tegenstelling tot Van Gaalen en Dykstra (2006) namen wij in onze selectie wel dyades mee waarin ouder en kind geen contact met elkaar hadden. Dit betreft $N=212$ dyades uit ronde 1 en $N=127$ dyades uit ronde 2. Van Gaalen en Dykstra namen deze dyades niet mee, omdat er geen informatie was over uitwisselingen van steun en de mate van conflict. In de NKPS werden deze vragen niet gesteld als respondenten al twaalf maanden of langer geen contact hadden met hun ouders. Wij hebben de betreffende dyades wel in de analyses opgenomen om te kunnen nagaan of er verschuivingen zijn van geen interactie naar enige interactie. Het meenemen van dyades waarin er geen contact is verschaft geeft een completer beeld van intergenerationele familierelaties en helpt om positieve vertekeningen te voorkomen. Omdat NKPS-respondenten over 
beide ouders konden rapporteren, hebben wij indien nodig één ouder willekeurig gekozen om problemen van afhankelijkheid te omzeilen. Onze uiteindelijke selectie bestond uit 5091 ouder-kindrelaties uit de eerste ronde en 3527 ouder-kindrelaties uit de tweede ronde.

\subsection{Metingen}

De latente klasseanalyse in dit artikel is gebaseerd op dezelfde solidariteits- en conflictitems als die door Van Gaalen en Dykstra (2006) voor hun ronde 1 typologie zijn gebruikt. De metingen betreffen gedragingen geen gevoelens - die zowel de associatieve als functionele dimensies van intergenerationele familierelaties omvatten (Bengtson \& Roberts, 1991; Szydlik, 2008). De gevoelsdimensie, door ons gezien als zowel een motivatie voor, als gevolg van intergenerationele interactie (Suitor, Pillemer, Keeton, \& Robison, 1995), is niet meegenomen in de analyses. Verder is verondersteld dat de verschillende dimensies van solidariteit (Silverstein \& Litwak, 1993) en de verschillende dimensies van conflict (Clarke, Preston, Raksin, \& Bengtson, 1999) onderling geen additieve samenhang vertonen, evenmin als dat solidariteit en conflict elkaars tegenpolen zijn (Giarrusso, et al., 2005).

Persoonlijk contact en contact via telefoon, brief of e-mail in de afgelopen twaalf maanden werden apart gemeten. Twee dummyvariabelen geven aan of er minimaal maandelijks $(=1)$ of minder vaak $(=0)$ contact was. Praktische steun verleend en ontvangen werd gemeten door te vragen of het kind, respectievelijk de ouder, de ander had geholpen met zaken, zoals klusjes doen in huis, dingen lenen, ergens heen brengen, of vervoeren van spullen in de afgelopen drie maanden. De antwoorden werden gedichotomiseerd om nooit $(=0)$ te onderscheiden van een enkele keer of meerdere keren $(=1)$. Ontvangst van financiële steun werd gemeten door te vragen of het kind de laatste twaalf maanden waardevolle spullen of een flink geldbedrag van de ouder had ontvangen $(0=$ niet, $1=$ wel). Uitwisseling van emotionele steun werd vastgesteld door na te gaan of zowel ouder als kind de laatste drie maanden interesse in elkaars persoonlijke leven hadden getoond $(0=$ niet, $1=$ wel $)$. Conflict werd gemeten door te vragen: 'Hebt $\mathrm{u}$ in de afgelopen drie maanden wel eens conflicten, spanningen of onenigheid ervaren met [ ouder ]'. Wanneer respondenten aangaven een enkele keer of meerdere keren conflict met de ouder gehad te hebben werd een lijst met mogelijke conflicten gepresenteerd. In de tweede ronde van de NKPS werden meer antwoordcategorieën aangeboden dan in de eerste ronde. Onze analyses beperken zich tot de categorieën die in beide rondes werden aangeboden. Conflicten over geld, bezittingen of erfenis, of andere praktische zaken werden gecombineerd in één meting van conflicten over praktische zaken $(0=$ 
niet, $1=$ wel). Conflicten over levensbeschouwing en normen en waarden, en over de relatie zelf werden gecombineerd in één meting van conflicten over persoonlijke zaken $(0=$ niet, $1=$ wel). Dyades waar er geen contact was geweest in het afgelopen jaar kregen de waarde 0 op de praktische en persoonlijke conflictitems.

De volgende transities $(0=$ niet, $1=$ wel $)$ tussen de eerste en tweede ronde werden meegenomen in de analyses: opnieuw trouwen of het aangaan van een nieuwe partnerrelatie door ouder of kind ('(her)partneren'), scheiding of verbreking van een partnerrelatie door ouder of kind ('scheiding'), het overlijden van de partner van de ouder ('verweduwing'), het ernstig ziek of invalide worden van de ouder ('verslechtering gezondheid'), het werkloos worden van het volwassen kind ('werkloosheid'), de geboorte van een kind van het volwassen kind ('geboorte kleinkind'), een verhuizing van ouder of kind waardoor de afstand tussen de twee kleiner dan ('verhuizing dichterbij') of groter dan ('verhuizing verderaf) 25 kilometer werd. Het geslacht van zowel ouder als kind (1 $=$ vrouw) werd ook meegenomen in de analyses. Vrouwen zijn in sterkere mate dan mannen gesocialiseerd om te reageren op de behoeften van anderen en om vervulling van hun eigen relationele behoeften te zoeken (Chodorow, 1978; Rossi \& Rossi, 1990). Dit zorgt er wellicht ook voor dat de relaties van vrouwen meer verschuivingen over de tijd laten zien. Een ander gezichtspunt is dat de relaties van vrouwen juist minder aan verschuiving onderhevig zijn. De seksegebonden structuur van familierelaties biedt vrouwen minder handelingsruimte om weerstand te bieden aan normatieve verplichtingen zoals hulp verlenen aan familieleden, en deze biedt ook minder handelingsruimte om met tegenstrijdige wensen van familieleden om te gaan (Acker, 1988; Aronson, 1992). Connidis en McMullin (2002) stellen meer in het bijzonder dat vrouwen minder mogelijkheden hebben om met ambivalentie om te gaan. Wij onthouden ons van het formuleren van hypothesen en nemen geslacht alleen mee om vast te stellen in hoeverre geslacht een rol speelt in de verschuivingen.

\subsection{Analyses}

Een voorwaarde om na te gaan in hoeverre er verschuivingen in latente klassen plaatsvonden, was dat de latente klassen gevonden op basis van de eerste ronde van de NKPS ook golden voor de tweede ronde. Eerst werd nagegaan of de meetmodellen voor ieder van de twee rondes gelijkwaardig waren. Daarna werd Latent Transition Analysis (LTA) in Mplus gebruikt om na te gaan in hoeverre verschuivingen tussen typen in de latente klassen plaatsvonden. De meetmodellen werden gebaseerd op alle beschikbare informatie. Gegevens van respondenten uit de eerste 
ronde die niet meer in de tweede ronde meededen werden dus wel voor het meetmodel gebruikt. Verschuivingen werden echter alleen in kaart gebracht voor de respondenten die in beide rondes hadden meegedaan. De meetmodellen op basis van alleen de respondenten uit beide rondes bleken overigens een gelijkwaardige typologie op te leveren. Ook zijn analyses verricht op basis van ordinale in plaats van dichotome items; de resultaten waren niet substantieel anders. We beperken ons tot de analyses op basis van dichotome items, omdat het lastiger is om de resultaten van ordinale latente klasse analyse te presenteren en interpreteren. Het is met LTA niet mogelijk om de data te wegen met behulp van longitudinale gewichten. In de eerdere analyses waarbij alleen gegevens uit de eerste ronde zijn gebruikt (Van Gaalen \& Dykstra, 2006), zijn gewichten wel toegepast. Bovendien hebben de betreffende onderzoekers de respondenten die geen contact hadden met hun familieleden niet meegenomen. Dat hebben wij wel gedaan. De typologieën zijn daarom niet helemaal vergelijkbaar.

Met behulp van logistische regressieanalyse is nagegaan in hoeverre transities tussen de twee rondes van de NKPS van voorspellende waarde waren voor verschuivingen in relatietypen. Hiervoor werden respondenten ingedeeld in het type waartoe zij volgens de analyses de grootste kans hadden om te behoren.

\section{Resultaten}

\section{I Beschrijvende resultaten}

Tabel 2 toont kenmerken van de steekproef en van de verdeling van de solidariteits- en conflictitems. Vrouwen waren enigszins oververtegenwoordigd in de steekproef. In de eerste ronde was $60 \%$ van de volwassen kinderen een dochter, in de tweede ronde $62 \%$. In de eerste ronde was $58 \%$ van de ouders een moeder, in de tweede ronde $59 \%$. Het verschil in leeftijd tussen ouder en kind was gemiddeld 30 jaar. De gemiddelde leeftijd was respectievelijk 67 en 38 in de eerste ronde en 70 en 41 in de tweede ronde (leeftijden niet gerapporteerd in tabel 2). De verdelingen voor de solidariteits- en conflictitems waren zeer gelijkwaardig over de twee rondes. Dit resultaat impliceert niet per se dat de respondenten gelijke antwoorden gaven op beide meetmomenten, maar uitsluitend dat het gemiddelde patroon ongeveer hetzelfde was in de twee rondes. Op beide tijdsmomenten had het overgrote deel van de respondenten minimaal maandelijks persoonlijk contact, minimaal maandelijks contact op een andere manier en minimaal maandelijks uitwisseling van emotionele steun. Respondenten rapporteerden vaker praktische hulp te hebben gegeven aan hun ouders (ongeveer 55\%) dan dat zij hulp van hun 
ouders hadden ontvangen (ongeveer $30 \%$ ). Ongeveer 20\% van de volwassen kinderen rapporteerde financiële steun van hun ouders te hebben ontvangen. Een kleiner maar nog steeds substantieel aantal respondenten rapporteerde conflict met hun ouders over materiële (ongeveer 10\%) en persoonlijke (13\%) zaken te hebben gehad. In de eerste ronde rapporteerde ongeveer $22 \%$ van de respondenten conflict over materiële of persoonlijke zaken. Dit percentage was iets lager in de tweede ronde $(17 \%$, niet gerapporteerd in tabel 2). Minder dan $2 \%$ van de respondenten rapporteerde beide vormen van conflict in de eerste ronde; dit percentage was $5 \%$ in de tweede ronde.

In tabel 2 is ook te zien hoe vaak bepaalde transities plaatsvonden. In het algemeen vonden er relatief weinig transities plaats tussen de twee rondes. Het slechter worden van de gezondheid van de ouder (16\%) en de geboorte van een kind van het volwassen kind (15\%) kwamen het vaakst

Tabel 2 Beschrijvende statistieken van de gebruikte items in de latente transitie analyse en van de levenstransities

\begin{tabular}{|c|c|c|}
\hline & Eerste ronde & Tweede ronde \\
\hline Eigenschappen van steekproef & $\%$ & $\%$ \\
\hline Geslacht van het kind (vrouw = I) & 60 & 61 \\
\hline Geslacht van de ouder (vrouw = I) & 58 & 59 \\
\hline Items in LTA & $\%$ & $\%$ \\
\hline Minimaal maandelijks persoonlijk contact & 79 & 82 \\
\hline Minimaal maandelijks ander contact & 76 & 79 \\
\hline Praktische steun gegeven $^{\mathrm{a}}$ & 52 & 58 \\
\hline Praktische steun ontvangen ${ }^{a}$ & 31 & 30 \\
\hline Financiële steun ontvangen ${ }^{a}$ & 22 & 21 \\
\hline Uitwisseling van emotionele steun & 84 & 87 \\
\hline Conflict over materiële zaken & 10 & 11 \\
\hline Conflict over persoonlijke zaken & 13 & 12 \\
\hline$N$ & 5091 & 3527 \\
\hline Levenstransitie & & $\%$ \\
\hline Herpartneren ouder & & 1 \\
\hline (Her)partneren kind & & 7 \\
\hline Scheiding ouder & & 0 \\
\hline Scheiding kind & & 6 \\
\hline Verweduwing ouder & & 7 \\
\hline Verslechtering gezondheid ouder & & 16 \\
\hline Werkloosheid kind & & 2 \\
\hline Geboorte kleinkind & & 15 \\
\hline Ouder of kind dichterbij verhuisd & & 2 \\
\hline Ouder of kind verder weg verhuisd & & 2 \\
\hline
\end{tabular}

${ }^{a}$ Gezien vanuit het perspectief van het kind.

Alle gebruikte variabelen waren dummy variabelen. 
voor. Verweduwing van de ouder (7\%), scheiding van het volwassen kind $(7 \%)$, en herpartneren van de ouder (6\%) kwamen daarna het vaakst voor. Twee procent van de kinderen werd werkloos tussen de twee rondes. In $2 \%$ van de dyades vond een verhuizing plaats waarbij de afstand tussen ouder en kind, die eerst groter dan 25 kilometer was, nu kleiner of gelijk aan 25 kilometer werd. Ook vond in $2 \%$ van de dyades de tegenovergestelde verhuisbeweging plaats. Overigens woonde meer dan de helft van de ouders binnen een afstand van 10 kilometer van het volwassen kind.

\subsection{Het reproduceren van de typologie van ouder-kindrelaties}

Doordat we dezelfde dataset gebruikten als Van Gaalen en Dykstra (2006), is het niet verrassend dat ook wij vonden dat een model met vijf latente klassen het best bij de data uit de eerste ronde paste. Wat betreft de data uit de tweede ronde was het beeld iets minder eenduidig. Op basis van een vergelijking van de BIC-waarden van modellen met 4, 5 en 6 latente klassen bleek dat een model met 5 klassen het beste bij de data paste. Een likelihood-ratiotest noopte ons echter echter dit model te verwerpen. Het model met 5 klassen was dus wel relatief het beste, maar paste in absolute zin niet goed bij de data. De entropiewaarden, die aangeven hoe nauwkeurig op basis van de gebruikte indicatoren het toebehoren aan een bepaalde klasse voorspeld kan worden, waren voor beide rondes echter redelijk hoog (boven de 0,75 ). In onze ogen was het geoorloofd om verder te gaan met de LTA, mede omdat ook de meetmodellen van beide rondes zeer gelijkwaardig waren.

Zoals eerder beschreven, werd in de tweede ronde een langere lijst met mogelijke conflictonderwerpen aan de respondenten voorgelegd dan in de eerste ronde. Onze analyses beperkten zich tot de mogelijkheden die in beide rondes werden geboden. Hoewel het verschil in de wijze van meten subtiel leek, had het een duidelijk effect op ons meetmodel in ronde 2 ten opzichte van dat van ronde 1 . We hebben de meetinconsistenties opgelost door de kansen van de latente klasse indicatoren voor het harmonieuze type vast te zetten op nul. Zodoende werd afgedwongen dat dit deel van het meetmodel gelijk was aan dat op basis van de eerste ronde.

Tabel 3 toont in hoeverre het 'wel' ten opzichte van 'niet' scoren op een bepaald item de kans om te worden ingedeeld in een bepaalde latente klasse verhoogt. Omdat de meetmodellen over beide rondes aan elkaar gelijk zijn gesteld, is er maar één verzameling van kansen die de meetmodellen van zowel de eerste als tweede ronde beschrijft. Zo is bijvoorbeeld uit de tabel af te leiden dat in relaties geclassificeerd als harmonieus, de kans op het hebben van minstens maandelijks persoonlijk contact 0,99 is. De verschillen in kansen tussen de onderhavige analyse 
Tabel 3 Latente klasse analyse van ouder-kindrelaties op twee tijdspunten (kansen)

\begin{tabular}{|c|c|c|c|c|c|}
\hline & Harmonieus & Ambivalent & Verplicht & Affectief & Verwijderd \\
\hline Ronde I \% & 34 & 26 & 18 & 14 & 7 \\
\hline Ronde $2 \%$ & 40 & 21 & 18 & 13 & 8 \\
\hline \multicolumn{6}{|l|}{ Solidariteit } \\
\hline $\begin{array}{l}\text { Minimaal maandelijks } \\
\text { persoonlijk contact }\end{array}$ & $0,99 * * *$ & $0,96 * * * *$ & $0,95 * * *$ & $0,19 * *$ & $0,04 * * *$ \\
\hline $\begin{array}{l}\text { Minimaal maandelijks ander } \\
\text { contact }\end{array}$ & $0,91 * * *$ & 0,92 **⿰冫⿰亅⿱丿丶丶 & $0,49 * * *$ & $0,87 * *$ & $0,04 * * *$ \\
\hline Praktische steun gegeven ${ }^{\mathrm{a}}$ & $0,62 * * *$ & $0,73 * * *$ & $0,54 * * * *$ & $0,22 *$ & $0,02 * * *$ \\
\hline $\begin{array}{l}\text { Praktische steun } \\
\text { ontvangen }^{\mathrm{a}}\end{array}$ & $0,44 * * *$ & $0,45 * * *$ & $0,12 * * *$ & 0,09 & $0,01 * * *$ \\
\hline Financiële steun ontvangen ${ }^{a}$ & $0,22 * * *$ & 0,34 **** & $0,08 * * *$ & 0,22 & $0,04 * * *$ \\
\hline $\begin{array}{l}\text { Uitwisseling van emotionele } \\
\text { steun }\end{array}$ & $0,99 * * *$ & $0,95 * * *$ & $0,65 * * *$ & $0,92 * * *$ & $0,12 * * *$ \\
\hline \multicolumn{6}{|l|}{ Conflict } \\
\hline $\begin{array}{l}\text { Conflict over materiële } \\
\text { zaken }\end{array}$ & $0,00 \mathrm{~b}$ & $0,31 * * * *$ & $0,09 * * *$ & $0,06 * * *$ & $0,04 * * *$ \\
\hline $\begin{array}{l}\text { Conflict over persoonlijke } \\
\text { zaken }\end{array}$ & $0,00 \mathrm{~b}$ & $0,34 * * * *$ & $0,10 * * *$ & $0,12 * * *$ & $0,13 * * *$ \\
\hline
\end{tabular}

$*=p<0,05 ; * *=p<0,01 ; * * *=p<0,001$.

${ }^{a}$ Gezien vanuit het perspectief van het kind.

${ }^{b}$ Kansen van deze items werden vastgezet op 0 .

en die van Van Gaalen en Dykstra (2006) zijn op één uitzondering na niet groter dan 0,1. De enige uitzondering is de kans op het hebben van minimaal maandelijks persoonlijk contact met de ouder in het affectieve type. De kans nam toe van 0,03 naar 0,19, maar bleef beperkt. De algemene patronen die de verschillende typen kenmerken, zijn zeer vergelijkbaar tussen beide analyses. Zo blijft bijvoorbeeld het ambivalente type het enige type met substantiële kansen op conflict over materiële en persoonlijke zaken. Het harmonieuze type lijkt weer sterk op het ambivalente type wat betreft de grote kans op contact en emotionele steun, matige kansen op de uitwisseling van praktische hulp en het ontvangen van financiële hulp. Het verplichte type is wederom gekenmerkt door een hoge kans op persoonlijk contact, matige kans op emotionele steun en het geven van praktische steun, maar een lage kans op het ontvangen van financiële of praktische steun van de ouders. In het affectieve type is de kans op uitwisseling van emotionele steun groot, net zoals de kans op andere vormen van contact dan persoonlijk. De kans op persoonlijk contact is klein en de kans op uitwisseling van praktische steun is vergeleken met de andere typen laag. De kans op het ontvangen van financiële steun is matig. Tot slot zijn in het verwijderde type de kansen op alle dimensies van solidariteit laag, terwijl de kansen op conflict relatief groot zijn. 
Tabel 4 Kansen op verschuivingen in type ouder-kindrelatie tussen ronde 1 en ronde 2

\begin{tabular}{lccccc}
\hline \multicolumn{5}{c}{ Ronde 2 } \\
\hline Ronde I & Harmonieus & Ambivalent & Verplicht & Affectief & Verwijderd \\
\hline Harmonieus & 0,98 & 0,02 & 0,00 & 0,00 & 0,01 \\
Ambivalent & 0,20 & 0,78 & 0,00 & 0,02 & 0,00 \\
Verplicht & 0,00 & 0,00 & 0,95 & 0,00 & 0,05 \\
Affectief & 0,09 & 0,03 & 0,00 & 0,84 & 0,04 \\
Verwijderd & 0,00 & 0,05 & 0,01 & 0,05 & 0,89 \\
\hline
\end{tabular}

De verdeling van relaties over de verschillende typen wijkt enigszins af van de oorspronkelijke analyse. De verdeling in Van Gaalen en Dykstra (2006) was: harmonieus (40\%), ambivalent (29\%), verplicht (16\%), affectief (11\%) en verwijderd (4\%). In de huidige analyse was de verdeling als volgt: harmonieus (34\%), ambivalent (26\%), verplicht (18\%), affectief (14\%) en verwijderd $(7 \%)$.

Zoals is te zien in tabel 4 , kwamen verschuivingen van het ambivalente en affectieve het vaakst voor. Verschuivingen van de harmonieuze en verplichte typen kwamen niet vaak voor, terwijl verschuivingen naar deze typen juist het vaakst voorkwamen. De kans op een verschuiving van een ambivalent naar een harmonieus type relatie was verreweg het grootst $(0,20)$. Verschuivingen van het ambivalente type naar andere dan het harmonieuze type waren onwaarschijnlijk. Verschuivingen van het affectieve type waren niet geconcentreerd in de richting van een bepaald type. De kans op een verschuiving naar het harmonieuze type was het grootst $(0,09)$, maar affectieve relaties verschoven ook naar ambivalente $(0,03)$ en verplichte $(0,04)$ typen. De kans op een verschuiving van het verplichte type naar het verwijderde type was 0,05 . Verschuivingen van het verwijderde type waren het waarschijnlijkst in de richting van de ambivalente $(0,05)$ en affectieve $(0,05)$ typen.

$\mathrm{Na}$ het classificeren van ouder-kinddyades in de waarschijnlijkste latente klasse in respectievelijk de eerste en tweede ronde, bleek dat 158 $(4,5 \%)$ van de relaties waren verschoven van type. Omdat er zowel in absolute als relatieve zin maar weinig verschuivingen plaatsvonden, was het niet mogelijk om de determinanten van alle mogelijke verschuivingen te onderzoeken. In de analyses hebben we ons beperkt tot verschuivingen die niet alleen in relatieve maar ook in absolute zin redelijk vaak voorkwamen (zie tabel 4). Hoewel de kans op verschuivingen naar het ambivalente type groot lijkt, gaat het in absolute zin maar om weinig relaties, omdat de verschuivingen typen betreffen die weinig voorkwamen. Wij richten ons daarom op verschuivingen naar het harmonieuze en verwijderde type en verschuivingen van het ambivalente type. Omdat er in totaal maar 158 verschuivingen waren, is het aantal verschuivingen van of naar een bepaald type nog vele malen kleiner. In een aantal gevallen 
deden bepaalde verschuivingen en bepaalde transities zich samen niet voor. In dergelijke gevallen waren we niet in staat om de coëfficiënten behorende bij de transities te schatten, zoals in tabel 5 is aangegeven. In tabel 5 is verder te zien of, voor zover verschuivingen plaatsvonden, ze te voorspellen waren aan de hand van de onderscheiden levenstransities, of het geslacht van de ouder of het kind. Drie aparte logistische regressieanalyses zijn uitgevoerd. In de inleiding hebben we geen hypothesen geformuleerd over levenstransities en de kans op verschuivingen van het ambivalente type. Alle hypothesen over levenstransities betreffen verschuiving naar een bepaald type. Om redenen van consistentie hanteren we toch dezelfde reeks van indicatoren in ieder van de analyses. Opgemerkt moet worden dat de onzekerheid over de geschatte coëfficiënten groot is, omdat de aantallen klein zijn.

We waren met geen van de indicatoren in staat om een verschuiving naar het harmonieuze type te voorspellen. Voor wat betreft verschuivingen naar het verwijderde type was er een sterk significant effect van het herpartneren van de ouder. Wanneer de ouder opnieuw trouwde of opnieuw een partnerschap aanging was de kansverhouding op een verschuiving naar het verwijderde type 5,58 keer groter dan wanneer de partnerstatus van de ouder niet veranderde. Hoewel het effect significant was, is de onzekerheid - waarschijnlijk door de eerder genoemde redenen - erg groot. Geen van de andere voorspellers had een signifi-

Tabel 5 Resultaten van logistische regressies ter voorspelling van verschuivingen in type ouder-kindrelatie (odds-ratios)

\begin{tabular}{|c|c|c|c|}
\hline Verschuivingen van/naar & Naar & Naar & Van \\
\hline Type ouder-kindrelatie & Harmonieus & Verwijderd & Ambivalent \\
\hline Geslacht van het kind (vrouw $=1$ ) & 1,16 & 0,73 & $1,97^{\dagger}$ \\
\hline Geslacht van de ouder (vrouw $=1$ ) & 1,16 & $\mathrm{I}, 03$ & $2,33^{*}$ \\
\hline \multicolumn{4}{|l|}{ Levenstransitie } \\
\hline Herpartneren ouder & $\mathrm{I}, 05$ & $5,48 * *$ & a \\
\hline (Her)partneren kind & 1,12 & 1,20 & 1,36 \\
\hline Scheiding ouder & a & a & a \\
\hline Scheiding kind & 0,97 & 0,69 & 1,52 \\
\hline Verweduwing ouder & $\mathrm{I}, 72$ & 1,16 & 0,37 \\
\hline Verslechtering gezondheid ouder & 1,09 & 0,74 & 0,80 \\
\hline Werkloosheid kind & 0,75 & a & 2,25 \\
\hline Geboorte kleinkind & $\mathrm{I}, 08$ & $\mathrm{I}, 4 \mathrm{I}$ & $\mathrm{I}, 4 \mathrm{I}$ \\
\hline Ouder of kind dichterbij verhuisd & $\mathrm{I}, 4 \mathrm{I}$ & a & 2,12 \\
\hline Ouder of kind verder weg verhuisd & 1,32 & I,85 & $3,66^{\dagger}$ \\
\hline
\end{tabular}

$\dagger=p<0,10 ; *=p<0,05 ; * *=p<0,01$.

${ }^{a}$ Effect niet te schatten door lege cellen.

Drie verschillende logistische regressiemodellen werden geschat, voor iedere verschuiving één. 
cant effect. Zoals uit tabel 5 blijkt hadden relaties met moeders een 2,33 grotere kansverhouding dan met vaders op een verschuiving van het ambivalente type. De resultaten suggereren eenzelfde effect voor dochters, maar dit is slechts significant bij $p<0,10$. Het verhuizen naar een afstand van meer dan 25 kilometer vergrootte de kansverhouding op een verschuiving van het ambivalente type. Ook dit effect was alleen significant bij $p<0,10$. Geen andere indicatoren konden verschuiving van het ambivalente type voorspellen.

\section{Discussie}

Over een periode van drie jaar blijkt er vooral stabiliteit en maar weinig verandering in volwassen ouder-kindrelaties te zijn. Onze resultaten tonen aan dat er nauwelijks verschuivingen in relatietype voorkomen; minder dan $5 \%$ van de relaties verschuift naar een ander type. Het lijkt erop dat patronen van intergenerationele interactie en communicatie die mensen naar de volwassenheid meenemen nauwelijks meer veranderen. Eerder onderzoek over de stabiliteit van intergenerationele interacties heeft zich vooral gericht op subjectieve aspecten van de relatie met ouders (Kaufman \& Uhlenberg, 1998; Tubman \& Lerner, 1994), is gebaseerd op retrospectieve rapportages van de ouder-kindrelatie (Rossi \& Rossi, 1990), of heeft gebruikgemaakt van een combinatie van subjectieve maten en gedragingen (Aquilino, 1997; Bucx et al., 2008). Uit onze studie blijkt continuïteit, maar dan op basis van rapportages over feitelijke gedragingen. Shen en Killian (2009) rapporteerden eveneens een hoge mate van stabiliteit in de tijd, maar dan van financiële steun tussen ouders en volwassen kinderen. Zij richtten zich op uitwisselingen van geld gedurende een periode van zes jaar. Het geven of ontvangen van financiële steun in eerdere jaren was een zeer goede voorspeller voor het geven of ontvangen van financiële steun in latere jaren.

Onze studie omvat een grotere leeftijdsgroep dan in eerder onderzoek gebruikelijk is geweest. Eerder onderzoek heeft zich vooral op adolescenten en jongvolwassenen gericht, vermoedelijk omdat de overgang naar volwassenheid een periode is waarin de relatie met ouders wordt heronderhandeld. We kunnen de mogelijkheid niet uitsluiten dat een exclusievere blik op de jongvolwassenheid meer fluctuaties in intergenerationele relaties zou hebben opgeleverd. Eerder longitudinaal onderzoek waarin kinderen werden gevolgd van de adolescentie naar de jongvolwassenheid toonden echter weinig grote effecten van transities in het leven van de kinderen op de relatie met hun ouders (Aquilino, 1997; Kiecolt et al., 2011).

Het zou natuurlijk zo kunnen zijn dat het gebrek aan verschuivingen te wijten is aan de lage frequentie van transities. De transitie die het 
vaakst voorkwam in het leven van de volwassen kinderen was de geboorte van een kind. Voor ouders was dit een verslechtering van de gezondheid. Verandering in partnerstatus van zowel kinderen als ouders kwam daarna het meest voor, maar slechts bij minder dan $10 \%$. Verschuivingen kwamen niettemin aanzienlijk minder vaak voor dan de op zichzelf al redelijk uitzonderlijke transities. Dit suggereert dat er vooral continuiteit bestaat in de verschillende vormen van solidariteit en conflict in ouder-kindrelaties ondanks de veranderingen die zich in de levens van volwassen kinderen en hun ouders voordoen.

Zoals beschreven in de inleiding, richt het overgrote deel van het onderzoek naar de gevolgen van levenstransities zich op losse dimensies van relaties zoals gepercipieerde kwaliteit, de mate van contact, of uitwisseling van steun. Het is denkbaar dat onderzoek dat zich richt op slechts een enkel aspect van intergenerationele relaties een overschatting geeft van de mate waarin deze aan verandering onderhevig zijn. Een typologie, die verschillende dimensies van relaties verenigt, is daarom wellicht een beter instrument om veranderingen in familierelaties te onderzoeken.

Naar onze mening is het kleine aantal gevonden verschuiving evenmin te wijten aan selectie. Zoals eerder beschreven, vormt de groep respondenten uit de tweede ronde wat betreft relatiekwaliteit geen selecte groep van alle deelnemers uit de eerste ronde. Respondenten uit de eerste ronde die rapporteerden nauwe familiebanden te hebben, waren even geneigd om mee te doen in de tweede ronde als respondenten met minder nauwe banden. Wel moet worden opgemerkt dat het aantal respondenten zonder contact met de ouders in de tweede ronde aanzienlijk kleiner was dan in de eerste ronde (127 versus 212). Mogelijk is er een hogere uitval geweest onder degenen zonder contact. In vergelijking met de omvang van de totale steekproef zijn de aantallen mogelijke uitvallers echter betrekkelijk klein. Wij hebben er vertrouwen in dat onze resultaten niet zijn gebaseerd op een vertekende steekproef van Nederlanders met opmerkelijk stabiele intergenerationele familiebanden.

Een andere mogelijkheid is dat onze metingen te grof zijn om veranderingen in relaties waar te nemen. Het is gebruikelijk om geen ordinale maar dichotome indicatoren in latente klasse analyses van intergenerationele relaties mee te nemen (Dykstra \& Fokkema, 2010; Giarrusso et al., 2005; Hogan, et al., 1993; Silverstein \& Bengtson, 1997; Silverstein et al., 2010). Hoewel het dichotomiseren een verlies aan informatie impliceert, zorgt het wel voor een goed hanteerbaar aantal cellen in de latente klasse analyse. Zoals eerder vermeld, leverde het gebruik van ordinale variabelen geen substantiële verschillen in typologie op. Vandaar dat we betwijfelen of metingen met een groter aantal antwoordcategorieën een grotere variatie in intergenerationele relaties over de tijd zouden laten zien. 
Voor zover er verschuivingen plaatsvonden, waren deze vooral verschuivingen van het ambivalente type. Dit is precies wat wij verwachtten op basis van het idee dat ambivalente relaties het meest onderhevig aan heronderhandeling zijn (Connidis \& McMullin, 2002). Ambivalente relaties neigden vooral naar verschuivingen in de richting van het harmonieuze type. Het verschil tussen beide typen ligt primair in de kans op het aanwezig zijn van conflict. Blijkbaar is ambivalentie in ouderkind relaties van tijdelijke aard. Wanneer de conflicten voorbij zijn, gaat men op een constructieve manier weer met elkaar om.

Relaties met moeders en dochters hadden vergeleken met relaties met vaders en zoons een grotere kans op een verschuiving van het ambivalente type. Ons inziens is dit resultaat de weerspiegeling van de grotere neiging van vrouwen om actief aan de oplossing van conflict in relaties te werken. Mannen zijn eerder geneigd om een passievere rol aan te nemen, een genderspecifiek patroon dat pursuit-withdrawal (achtervolging-terugtrekking) wordt genoemd (Rausch, Barry, Hertel, \& Swain, 1974). Meer algemeen zijn de resultaten in overeenstemming met het vaak-gerapporteerde patroon dat de familierelaties van vrouwen meer intens en allesomvattend zijn dan die van mannen (Fingerman, 2001). Ze zijn echter in tegenspraak met wat Connidis en McMullin (2002) stellen, namelijk dat vrouwen meer beperkingen ervaren bij het omgaan met ambivalentie. Deze tegenstrijdigheid is wellicht het gevolg van een andere conceptualisering van ambivalentie. Connidis en McMullin (2002) benadrukken de tegenstrijdige eisen en verwachtingen van individuen, hun familie en de samenleving. Degenen met minder voorrechten - onder wie vrouwen - hebben minder middelen om ambivalentie te reduceren. Onze conceptualisering, die de gelijktijdige aanwezigheid van solidariteit en conflict centraal stelt, heeft een sterke gerichtheid op relaties en past goed bij de kinkeeping rol die vrouwen binnen families spelen (Hagestad, 1986).

De lage frequentie beperkte ons helaas in de analyse van voorspellers van verschuivingen. Soms was het helemaal niet mogelijk om bepaalde variabelen te gebruiken en slechts enkele coëfficiënten lieten een significant effect zien. Het was bijvoorbeeld niet mogelijk om ouderlijke scheiding als een voorspeller te gebruiken omdat scheiding samen met verschuiving in relatie type helemaal niet voor kwam. Geen van de volgende levenstransities voorspelde een verschuiving in relatie type: (her) partneren van het kind, scheiding van het kind, verweduwing van de ouder, verslechtering van de gezondheid van de ouder, werkloosheid van het kind, de geboorte van een kleinkind en dichterbij elkaar gaan wonen. Blijkbaar worden deze transities opgenomen in de alledaagse stroom van interacties tussen familieleden. Enige voorzichtigheid met deze conclusie is echter geboden, omdat het gebrek aan significante 
resultaten ook deels te wijten kan zijn aan het kleine aantal verschuivingen in onze data. Een alternatieve interpretatie is dat onze resultaten specifiek voor familierelaties in Nederland zijn omdat Nederland, net zoals de Scandinavische landen, genereuze welvaartsvoorzieningen heeft die het volwassen kinderen en hun ouders mogelijk maken om betrekkelijk onafhankelijk van elkaar te zijn (Saraceno \& Keck, 2010). Vergelijkbare analyses op basis van data uit andere landen zouden meer inzicht kunnen bieden.

Twee transities bleken significante voorspellers te zijn voor verschuivingen: herpartneren van de ouder en verder weg verhuizen. Herpartneren van de ouder viel samen met een verschuiving naar het verwijderde type met zijn lage kans op contact en uitwisseling van steun en relatief hoge kans op conflict over persoonlijke zaken. Conform eerder onderzoek vinden wij dat wanneer de ouder een nieuwe partnerrelatie aangaat, de mate van contact afneemt (Bucx, 2008; De Jong Gierveld \& Peeters, 2003; De Graaf \& Fokkema 2007; Lye, Klepinger, Hyle, \& Nelson, 1995). Interessant is echter dat het gebruik van een typologie laat zien dat de nieuwe partnerrelatie er ook voor zorgt dat de kans op spanningen in de relatie met de kinderen toeneemt. Volgens De Jong Gierveld en Peeters (2003) kunnen kinderen zich ongemakkelijk gaan voelen, omdat de plaats van de biologische ouder wordt ingenomen. Ook kan het zijn dat wrevel ontstaat omdat het ouderlijk huis wordt bewoond door de nieuwe partner, of vanwege onzekerheid over een verwachte erfenis. Verder weg verhuizen viel samen met een verschuiving van het ambivalente type. Verder weg verhuizen kan gezien worden als een vluchtroute die de kans op ambivalentie vermindert (Van Gaalen et al., 2010). Een grotere geografische afstand tussen familieleden maakt het mogelijk voor familieleden om zichzelf los te maken van de intensiteit van intergenerationele ambivalentie met zijn mengsel van solidariteit en conflict.

\section{Noot}

1. Pearl A. Dykstra is hoogleraar en Niels Schenk is wetenschappelijk onderzoeker bij de Capacititeitsgroep Sociologie van de Erasmus Universiteit Rotterdam. Correspondentieadres: Pearl A. Dykstra, Capaciteitsgroep Sociologie, Erasmus Universiteit Rotterdam, Postbus 1738, 3000 DR Rotterdam, e-mail: dykstra@fsw. eur.nl. De gegevens zijn van de Netherlands Kinship Panel Study (NKPS), waarvoor financiering is verkregen van het fonds Investeringen Groot van de Nederlandse Organisatie voor Wetenschappelijk Onderzoek (NWO) en van het NWO subsidieinstrument Veranderingsstudies. Aanvullende financiële en institutionele steun voor de NKPS is afkomstig van het Nederlands Interdisciplinair Demografisch Instituut, de Koninklijke Akademie van Wetenschappen, de Universiteit Utrecht, de Universiteit van Amsterdam, de Universiteit van Tilburg en de Erasmus Universiteit Rotterdam. Het artikel is geschreven in het kader van het project MULTILINKS (How Demographic Changes Shape Intergenerational Solidarity, Well-being, and 
Social Integration: A multilinks framework), een onderzoek gefinancierd via het Zevende Kaderprogramma van de Europese Commissie. Eerdere versies van het artikel zijn gepresenteerd tijdens de internationale pairfam-Conferentie over intergenerationele relaties in Chemnitz (22-24 september, 2010), de bijeenkomst van de Amerikaanse Gerontologische Vereniging (GSA) in New Orleans (19-23 november, 2010), en de Alpine Bevolkingsconferentie in La Thuile (9-12 januari, 2011).

\section{Literatuur}

Acker, J. (1988). Class, gender, and the relations of distribution. Signs, 13, 473-97.

Ainsworth, M.D.S. (1989). Attachments beyond infancy. American Psychologist, 44, 709-716.

Amato, P.R. (2010). Research on divorce: Continuing trends and new developments. Journal of Marriage and Family, 72, 650-666.

Amato, P.R., Rezac, S.J., \& Booth, A. (1995). Helping between parents and young adult offspring: The role of parental marital quality, divorce, and remarriage. Journal of Marriage and Family, 57, 363-374.

Aquilino, W.S. (1997). From adolescent to young adult: A prospective study of parent-child relations during the transition to adulthood. Journal of Marriage and Family, 59, 670-686.

Aronson, J. (1992). Women's sense of responsibility for the care of old people: "But who else is going to do it?" Gender and Society, 6, 8-29.

Attias-Donfut, D., Ogg, J., \& Wolff, F. (2005). European patterns of intergenerational financial and time transfers. European Journal of Ageing, 2, 161-173.

Bengtson, V., Giarrusso, R., Mabry, J.B., \& Silverstein, M. (2002). Solidarity, conflict, and ambivalence: Complementary or competing perspectives on intergenerational relationships? Journal of Marriage and Family, 64, 568-576.

Bengtson, V.L., \& Roberts, R.E.L. (1991). Intergenerational solidarity in aging families: An example of formal theory construction. Journal of Marriage and the Family, 53, 856-870.

Birditt, K.S., Fingerman, K.L., \& Zarit, S.H. (2010). Adult children's problems and successes: Implications for intergenerational ambivalence. Journals of Gerontology: Psychological Sciences, 65B, P145-P153.

Bucx, F. (2009). Linked lives: Young adults' life course and relations with parents. Proefschrift Universiteit Utrecht.

Bucx, F., Van Wel, F., Knijn, T., \& Hagendoorn, L. (2008). Intergenerational contact and the life course status of young adult children. Journal of Marriage and Family, 70, 144-156. 
Chodorow, N. (1978). The reproduction of mothering: psychoanalysis and the sociology of gender. Berkeley: University of California Press.

Cicirelli, V.G. (1988). A measure of filial anxiety regarding anticipated care of elderly parents. The Gerontologist, 28, 478-482.

Clarke, E.J., Preston, M., Raksin, J., \& Bengtson, V.L. (1999). Types of conflicts and tensions between older parents and adult children. The Gerontologist, 39, 261-270.

Connidis, I.A. (2010). Family ties and aging (2e ed.). Londen: Pine Forge Press/Sage.

Connidis, I.A., \& McMullin, J.A. (2002). Sociological ambivalence and family ties: A critical perspective. Journal of Marriage and Family, 64, 558-567.

Coser, L., \& Coser, R. (1974). Greedy institutions: Patterns of undivided commitment. New York: Free Press.

Couch, K.A., Daly, M.C., \& Wolf, D.A. (1999). Time? Money? Both? The allocation of resources to older parents. Demography, 36, 219-232.

Diepen, A.M.L. van \& Mulder, C.H. (2009). Distance to family members and relocations of older adults. Journal of Housing and the Built Environment, 24, 31-46.

Durkheim, E. (1951). Suicide: A study in sociology. Glencoe, IL: Free Press. (Eerste uitgave 1896)

Dykstra, P.A. (1997). The effects of divorce on intergenerational exchanges in families. The Netherlands Journal of Social Sciences, 3, 77-93.

Dykstra, P.A., \& Fokkema, T. (2011). Relationships between parents and their adult children: A West European typology of late-life families. Ageing \& Society, 31, 545-569

Dykstra, P.A., Kalmijn, M., Knijn, T.C.M., Komter, A.E., Liefbroer, A.C., \& Mulder, C.H. (2005). Codebook of the Netherlands Kinship Panel Study: A multi-actor, multi-method panel study on solidarity in family relationships, wave 1. Juli 2005, Versie 1. NKPS Working Paper No 5. Den Haag: Nederlands Interdisciplinair Demograpisch Instituut.

Dykstra, P.A., Kalmijn, M., Knijn, T.C.M., Komter, A.E., Liefbroer, A.C., \& Mulder, C.H. (2007). Codebook of the Netherlands Kinship Panel Study: A multi-actor, multi-method panel study on solidarity in family relationships, wave 2. Oktober 2007, Versie 0. NKPS Working Paper No 6. Den Haag: Nederlands Interdisciplinair Demograpisch Instituut.

Elder, G.H. Jr. (1994). Time, human agency, and societal change: Perspectives on the life course. Social Psychological Quarterly, 57, 4-15.

Finch, J., \& Mason, J. (1993). Negotiating family responsibilities. Londen: Tavistock/Routledge.

Fingerman, K.L. (2001). Aging mothers and their adult daughters: A study in mixed emotions. New York: Springer. 
Fingerman, K.L., Miller, L., Birditt, K. \& Zarit, S. (2009). Giving to the good and the needy: parental support of grown children. Journal of Marriage and Family, 71, 1220-1233.

Fingerman, K.L., Pitzer, L.M., Chan, W., Birditt, K., Franks, M.M., \& Zarit,

S. (2011). Who gets what and why? Help middle-aged adults provide to parents and grown children. Journals of Gerontology: Social Sciences, 66B, 87-98.

Fingerman, K.L., Pitzer, L., Lefkowitz, E.S., Birditt, K.S., \& Mroczek, D. (2008). Ambivalent relationship qualities between adults and their parents: Implications for the well-being of both parties. Journals of Gerontology: Psychological Sciences, 63B, P362-P371.

Gaalen, R.I. van \& Dykstra, P.A. (2006). Solidarity and conflict between adult children and parents: A latent class analysis. Journal of Marriage and Family, 68, 947-960.

Gaalen, R.I. van, Dykstra, P.A., \& Komter, A.E. (2010). Where is the exit? Intergenerational ambivalence and relationship quality in high contact ties. Journal of Aging Studies, 24, 105-114.

George, L.K. (1986). Caregiver burden: Conflict between norms of reciprocity and solidarity. In K.A. Pillemer \& R.S. Wolf (red.), Elder abuse: Conflict in the family (pp. 67-92). Dover, MA: Auburn House.

Giarrusso, R., Silverstein, M., Gans, D., \& Bengtson, V.L. (2005). Ageing parents and adult children: New perspectives on intergenerational relationships. In M.L. Johnson, V.L. Bengtson, P.G. Coleman \& T.B.L. Kirkwood (eds.), The Cambridge handbook of age and ageing (pp. 413-421). Cambridge: Cambridge University Press.

Glass, J., Bengtson, V.L., \& Dunham, C.C. (1986). Attitude similarity in three-generation families: Socialization, status inheritance, or reciprocal influence? American Sociological Review, 51, 685-698.

Graaf, P.M. de \& Fokkema, T. (2007). Contacts between divorced and nondivorced parents and their adult children in the Netherlands: An investment perspective. European Sociological Review, 23, 263-277.

Grotevant, H.D., \& Cooper, C.R. (1986). Individuation in family relationships. A perspective on individual differences in the development of identity and role-taking skills in adolescence. Human Development, 29, 82-100.

Grundy, E., \& Shelton, N. (2001). Contact between adult children and their parents in Great Britain 1986-99. Environment and Planning A, 33, 685-697.

Ha, J.-H. (2008). Changes in support from confidants, children, and friends following widowhood. Journal of Marriage and Family, 70, 306318.

Ha, J.-H., Carr, D., Utz, R.L., \& Nesse, R. (2006). Older adults' perceptions of intergenerational support after widowhood: How do men and women differ? Journal of Family Issues, 27, 3-30. 
Hagestad, G.O. (1986). The family: Women and grandparents as kinkeepers. In A. Pifer \& L. Bronte (red.), Our aging society: Paradox and promise (pp. 141-160). New York: Norton.

Hagestad, G.O. (2003). Interdependent lives and relationships in changing times: A life course view of families and aging. In R. Settersten (red.), Invitation to the life course: Toward new understandings of later life (pp. 135-159). Amityville, NY: Baywood.

Hank, K. (2007). Proximity and contacts between older parents and their children: A European comparison. Journal of Marriage and Family, 69, 157-173.

Hank, K., \& Buber, I. (2009). Grandparents caring for their grandchildren: Findings from the 2004 Survey of Health, Ageing, and Retirement in Europe. Journal of Family Issues, 30, 53-73.

Hank, K., \& Kreyenfeld, M. (2003). A multilevel analysis of child care and women's fertility decisions in Western Germany. Journal of Marriage and Family, 65, 584-596.

Hogan, D.P., Eggebeen, D.J., \& Clogg, C.C. (1993). The structure of intergenerational exchanges in American families. American Journal of Sociology, 98, 1428-1458.

Jong Gierveld, J. de, \& Peeters, A. (2003). The interweaving of repartnered older adults' lives with their children and siblings. Ageing 8 Society 23, 187-205.

Kalmijn, M. (2007). Gender differences in the effects of divorce, widowhood and remarriage on intergenerational support: Does marriage protect fathers? Social Forces, 85, 1079-1104.

Kaptijn, R., Thomese, F., Van Tilburg, T.G., \& Liefbroer, A.C. (2010). How grandparents matter: Support for the cooperative breeding hypothesis in a contemporary Dutch population. Human Nature, 21, 393-405.

Katz, R. (2009). Intergenerational family relations and subjective wellbeing in old age: A cross-national study. European Journal of Aging, 6, 79-90.

Katz, R., Lowenstein, A., Phillips, J., \& Daatland, S.O. (2005). Theorizing intergenerational family relations: Solidarity, conflict, and ambivalence in cross-national contexts. In V.L. Bengtson, A.C. Acock, K.R. Allen, P. Dilworth-Anderson, \& D. Klein (red.), Sourcebook of family theory \& research (pp. 393-407). Thousand Oaks, CA: Sage.

Kaufman, G., \& Uhlenberg, P. (1998). Effects of life course transitions on the quality of relationships between adult children and their parents. Journal of Marriage and Family, 60, 924-938.

Kiecolt, K.J., Blieszner, R., \& Savla, J. (2011). Long-term influences of intergenerational ambivalence on midlife parents' psychological wellbeing. Journal of Marriage and Family, 73, 369-382. 
Koh, S.-K., \& MacDonald, M. (2006). Journal of Family and Economic Issues, 27, 420-436.

Kohli, M. (1999). Private and public transfers between generations: Linking the family and the state. European Societies, 1, 81-104.

Lachman, M.E. (2004). Development in midlife. Annual Review of Psycho$\log y, 55,305-331$.

Litwak, E., \& Kulis, S. (1987). Technology, proximity, and measures of kin support. Journal of Marriage and the Family, 49, 649-661.

Lüscher, K. (2002). Intergenerational ambivalence: Further steps in theory and research. Journal of Marriage and Family, 64, 585-593.

Lüscher, K., \& Pillemer, K. (1998). Intergenerational ambivalence: A new approach to the study of parent-child relations in later life. Journal of Marriage and the Family, 60, 413-425.

Lye, D., Klepinger, D.H., Hyle, P.D., \& Nelson, A. (1995). Childhood living arrangements and adult children's relations with their parents. Demography, 32, 261-80.

Marcoen, A. (1995). Filial maturity of middle-aged adult children in the context of parent care: Model and measures. Journal of Adult Development, 2, 125-136.

McGarry, K., \& Schoeni, R.F. (1997). Transfer behavior within the family: Results from the Asset and Health Dynamics Study. Journals of Gerontology: Social Sciences, 52B, 82-92.

Merz, E.-M. (2010). Caring for your loved ones? An attachment perspective on solidarity between generations. Saarbrücken, Duitsland: Lambert Academic Publishing.

Moen, P., Robinson, J., \& Fields, V. (1994). Women's work and caregiving roles: A life course approach. Journals of Gerontology: Social Sciences, 49, S176-86.

Ogg, J., \& Renaut, S. (2006). The support of parents in old age by those born during 1945-1954: A European perspective. Ageing \& Society, 26, 723-43.

Pavalko, E.K., \& Artis, J.E. (1997). Women's caregiving and paid work: Causal relationships in late midlife. Journals of Gerontology: Social Sciences, 52B, S170-80.

Pillemer, K., \& Suitor, J.J. (2002). Explaining mothers' ambivalence toward their adult children. Journal of Marriage and Family, 64, 602-613.

Putten, A.E. van, Dykstra, P.A., Schippers, J.J., \& Vlasblom, J.D. (2010). The absence of conflict between paid-work hours and the provision of instrumental support to elderly parents among middle-aged women and men. Ageing \& Society, 30, 923-948.

Rausch, H.L., Barry, W.A., Hertel, R.K., \& Swain, M.A. (1974). Communication and conflict in marriage. San Francisco: Jossey-Bass. 
Roan, C.L., \& Raley, R.K. (1996). Intergenerational coresidence and contact: A longitudinal analysis of adult children's response to their mother's widowhood. Journal of Marriage and the Family, 58, 708-717.

Rossi, A.S., \& Rossi, P.H. (1990). Of human bonding: Parent-child relations across the life course. New York: Aldine de Gruyter.

Saraceno, C., \& Keck, W., (2010). Can we identify intergenerational policy regimes in Europe? European Societies, 12, 675-696.

Sarkisian, N., \& Gerstel, N. (2008). Till marriage do us part: Adult children's relationships with parents. Journal of Marriage and Family, 70, 360-376.

Schenk, N., Dykstra, P.A., \& Maas, I. (2010). The role of European welfare states in intergenerational monetary transfers: A micro-level perspective. Ageing \& Society, 30, 1315-1342.

Shapiro, A. (2003). Later-life divorce and parent-adult child contact and proximity: A longitudinal analysis. Journal of Family Issues, 24, 265-285.

Shapiro, A., \& Remle, R.C. (2010). Generational jeopardy? Parents'marital transitions and the provision of financial transfers to adult children. Journals of Gerontology: Social Sciences, 66B, 99-108.

Sheng, X., \& Killian, T.S. (2009). Over time dynamics of monetary intergenerational exchanges. Journal of Family and Economic Issues, 30, 268281.

Silverstein, M., \& Bengtson, V.L. (1997). Intergenerational solidarity and the structure of adult-parent relationships in American families. American Journal of Sociology, 103, 429-460.

Silverstein, M., Gans, D., Lowenstein, A., Giarrusso, R., \& Bengtson, V.L. (2010). Older parent-child relationships in six developed nations: Comparisons at the intersection of affection and conflict. Journal of Marriage and Family, 72, 1006-1021.

Silverstein, M., Gans, D. \& Yang F. M. (2006). Intergenerational support to aging parents: The role of norms and needs. Journal of Family Issues, 27, 1068-1084.

Silverstein, M., \& Giarrusso, R. (2010). Aging and family life: A decade review. Journal of Marriage and Family, 72, 1039-1058.

Silverstein, M., \& Litwak, E. (1993). A task-specific typology of intergenerational family structure in later life. The Gerontologist, 33, 258-264.

Smits, A., Gaalen, R.I. van, \& Mulder, C.H. (2010). Parent-child coresidence: Who moves in with whom and for whose needs? Journal of Marriage and Family, 72, 1022-1033.

Spitze, G., Logan, J.R., Deane, G., Zerger, S. (1994). Adult children’s divorce and intergenerational relationships. Journal of Marriage and Family, 56, 279-293.

Steinbach, A. (2008). Intergenerational solidarity and ambivalence: Types of relationships in German families. Journal of Comparative Family Studies, 39, 115-127. 
Suitor, J.J., Pillemer, K., Keeton, S., \& Robison, J. (1995). Aged parents and aged children: Determinants of relationship quality. In R. Blieszner \& V.H. Bedford (red.), Handbook of aging and the family (pp. 223-242). Westport, CT: Greenwood.

Szydlik, M. (2008). Intergenerational conflict and solidarity. Journal of Comparative Family Studies, 34, 97-114.

Tomassini, C., Wolf, D.A., \& Rosina, A. (2003). Parental housing assistance and parent-child proximity in Italy. Journal of Marriage and Family, 65, 700-715.

Tubman, J.G., \& Lerner, R.M. (1994). Affective experiences of parents and their children from adolescence to young adulthood: Stability of affective experiences. Journal of Adolescence, 17, 81-98.

Umberson, D. (1992). Relationships between adult children and their parents: Psychological consequences for both generations. Journal of Marriage and the Family, 54, 664-674.

United Nations Economic Commission for Europe (2007). Generations 8 Gender Programme: Concepts and guidelines. New York/Geneva: United Nations.

Vandell, D.L., McCartney, K., Owen, M.T., Booth, C., \& Clarke-Stewart, A. (2003). Variations in child care by grandparents during the first three years. Journal of Marriage and Family, 65, 375-381.

Wade-Benzoni, K., \& Tost, L.P. (2009). The egoism and altruism of intergenerational behavior. Personality and Social Psychology Review, 13, 165193.

White, L. (1992). The effect of parental divorce and remarriage on parental support for adult children. Journal of Family Issues, 13, 234-250.

White, L., \& Peterson, D. (1995). The retreat from marriage: Its effect on unmarried children's exchange with parents. Journal of Marriage and the Family, 57, 428-434.

Willson, A.E., Shuey, K.M., Elder, G.H., Jr., \& Wickrama, K.A.S. (2006). Ambivalence in in mother-adult child relations: A dyadic analysis. Social Psychology Quarterly, 69, 235-252. 